\title{
Road rage and road traffic accidents among commercial vehicle drivers in Lahore, Pakistan
}

\author{
M.A. Shaikh, ${ }^{7}$ I.A. Shaikh ${ }^{7}$ and Z. Siddiqui ${ }^{2}$
}

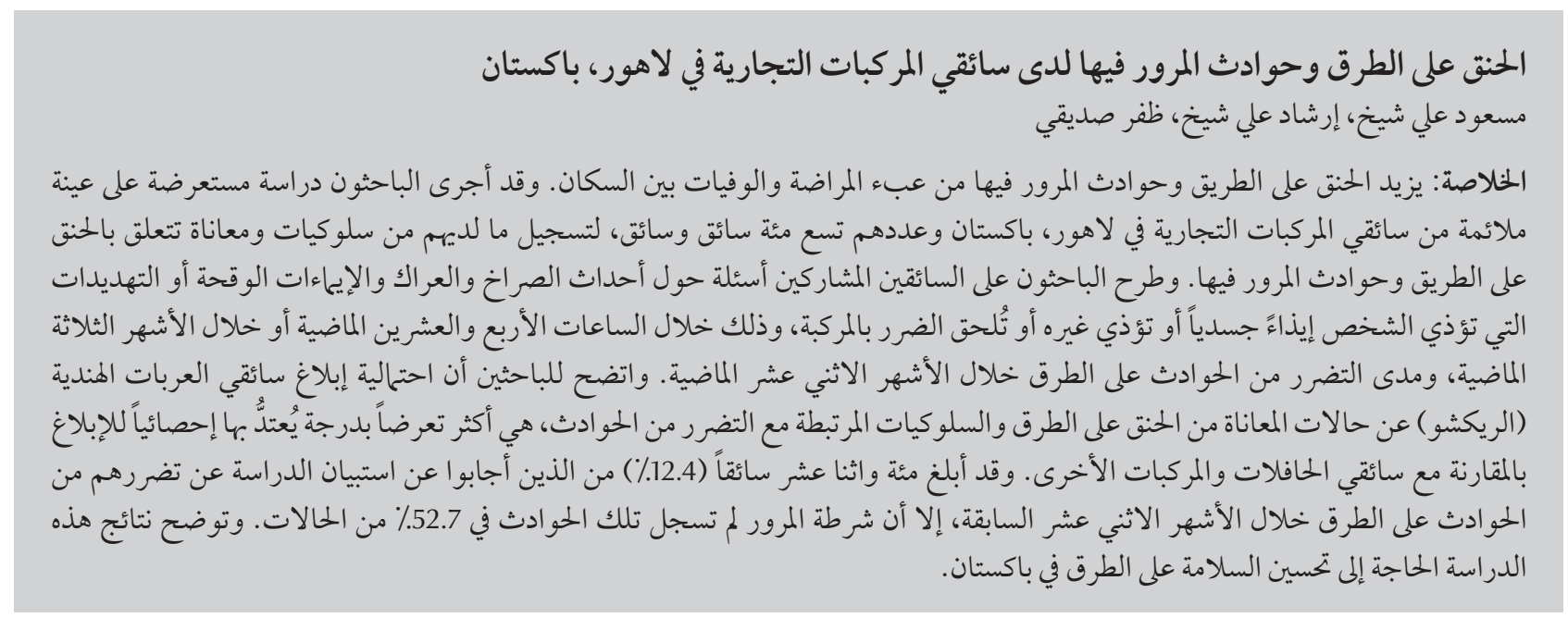

ABSTRACT Road rage and road traffic accidents increase the burden of morbidity and mortality in a population. A cross-sectional survey with convenience sampling was conducted among commercial vehicle drivers in Lahore, Pakistan $(n=901)$ to record their behaviours/experiences regarding road rage and road traffic accidents. Respondents were asked about incidents of shouting/cursing/rude gestures or threats to physically hurt the person/vehicle, by others or themselves, in the previous 24 hours or 3 months, and their involvement in road traffic accidents in the previous 12 months. Auto-rickshaw drivers were significantly more likely to report various road rage experiences/ behaviours and involvement in accidents compared with bus and wagon drivers. A total of 112 respondents (12.4\%) reported being involved in a road traffic accident in the previous 12 months but traffic police did not record the accident in $52.7 \%$ of cases. The results of this study underline the need to improve road safety in Pakistan.

Rage au volant et accidents de la circulation chez des conducteurs de véhicules utilitaires à Lahore (Pakistan)

RÉSUMÉ La rage au volant et les accidents de la circulation augmentent la charge de morbidité et la mortalité dans la population. Une enquête transversale fondée sur un échantillon de commodité a été menée auprès de conducteurs de véhicules utilitaires $(n=901)$ à Lahore (Pakistan) pour observer leurs comportements et leurs expériences concernant la rage au volant et les accidents de la circulation. Les participants à l'enquête ont été interrogés sur les incidents impliquant des agressions verbales, des jurons, des gestes insultants ou des menaces de violences physiques dirigées contre une personne et/ou un véhicule, par eux-mêmes ou par des tiers au cours des dernières 24 heures ou des trois derniers mois. L'enquête portait aussi sur leur implication dans des accidents de la circulation aus cours des douze derniers mois. Les conducteurs de rickshaw étaient davantage susceptibles de rapporter des expériences et/ou des comportements de rage au volant et des implications dans des accidents que les chauffeurs de bus ou de fourgons. Au total, 112 répondants $(12,4 \%)$ ont indiqué avoir été impliqués dans un accident de la circulation au cours des douze derniers mois, mais la police n'a pas enregistré l'accident dans $52,7 \%$ des cas. Les résultats de l'étude soulignent la nécessité d'améliorer la sécurité routière au Pakistan.

'Independent Consultancy, Tunis, Tunisia (Correspondence to M.A. Shaikh: masoodali1@yahoo.com). ${ }^{2}$ Public Health Physician Practice, Rawalpindi, Pakistan.

Received: 30/09/10; accepted: 21/12/10 


\section{Introduction}

Expressions or experiences of anger while driving or travelling on the road constitute road rage and include verbal abuse and threats and/or acts of physical harm. Road rage can end in serious consequence such as injury and death, and victims can become economically burdened [1-3]. Psychiatric diseases have also been linked to episodes of road rage in victims and perpetrators $[1,2]$. Research about road rage in the Eastern Mediterranean region is sparse. Few studies have been done in Pakistan; one reported that $30 \%$ of 532 university students had experienced road rage in the form of verbal abuse or rude gestures [4], while another study reported $88.6 \%$ of 156 bus drivers experiencing rude gestures as the most common form of road rage [5].

This study was conducted to understand more about road rage experiences and behaviours and the road traffic accident (RTA) profile among different types of commercial vehicle drivers in the city of Lahore in Pakistan.

\section{Methods}

A cross-sectional survey was conducted from February to May 2009 to record commercial vehicle drivers' behaviours and experiences regarding road rage and their involvement in RTAs. A convenience sample was taken of bus, auto-rickshaw and wagon drivers in Lahore at various stops on their designated routes, in frequently visited city areas and popular destinations. A wagon is a van that seats 12-18 people and an auto-rickshaw is 3-wheeler motor vehicle that usually seats 2 people and is a common mode of transport for hire in Pakistan. A total of 982 drivers were approached, and 901 agreed to be interviewed (a response rate of $91.8 \%$ ).

A trained interviewer administered a pre-tested, structured questionnaire with both open- and close-ended questions. Only drivers who had been driving for at least 1 year were interviewed, after obtaining verbal consent, either inside the vehicle or in a place close by where no one could overhear. Respondents were asked about incidents of shouting, cursing or rude gestures, or threats to physically hurt the person/vehicle, by others or themselves, in the previous 24 hours or previous 3 months (excluding the previous 24 hours). They were also asked about their involvement in RTAs in the previous 12 months. Injuries sustained to themselves or others as a result of the RTA were inquired about; injury was defined as one requiring self-treatment with a medication/ointment/bandage or treatment by a physician.

The data were analysed using open-source statistical analysis software package $R$, version 2.10.1, applying chi-squared and Fisher exact tests.

\section{Results}

Table 1 displays the demographic and other characteristics of commercial vehicle drivers by type of vehicle driven. The majority of commercial vehicle drivers $(73.7 \%)$ had no or $\leq 5$ years of schooling.

Table 2 shows the drivers' road rage behaviours and experiences by type of commercial vehicle driven. Auto-rickshaw drivers were more likely to report various road rage experiences and behaviours compared with the other 2 types of drivers. The most common types of road rage experience reported in the previous 24 hours, as well as in the previous 3 months, was someone in another vehicle shouting, cursing or making rude gestures. This was statistically significantly different among the 3 types of commercial vehicle drivers for all categories except personally threatening someone. Almost all respondents who had experienced or been themselves involved in road rage in the previous 24 hours had experienced this only once, and both the perpetrators and victims were primarily occupants of other commercial vehicle rather than privately owned vehicles $(71.6 \%$ commercial, $28.4 \%$. private).

Table 3 lists the frequency of involvement in RTAs by type of commercial vehicle driven. Although, cumulatively 112 respondents (12.4\%) were involved in a RTA in

\begin{tabular}{|c|c|c|c|c|c|c|}
\hline Characteristic & \multicolumn{2}{|c|}{$\begin{array}{c}\text { Bus } \\
(n=302)\end{array}$} & \multicolumn{2}{|c|}{$\begin{array}{l}\text { Auto-rickshaw } \\
\qquad(n=301)\end{array}$} & \multicolumn{2}{|c|}{$\begin{array}{c}\text { Wagon } \\
(n=298)\end{array}$} \\
\hline \multicolumn{7}{|l|}{ Education (years) (No., \%) } \\
\hline None & 101 & 33.4 & 61 & 20.3 & 80 & 26.8 \\
\hline $1-5$ & 156 & 51.7 & 135 & 44.9 & 131 & 44.0 \\
\hline $6-8$ & 36 & 11.9 & 64 & 21.3 & 55 & 18.5 \\
\hline $9-10$ & 9 & 3.0 & 41 & 13.6 & 32 & 10.7 \\
\hline Mean (SD) age (years) & \multicolumn{2}{|c|}{$44.8(3.8)$} & \multicolumn{2}{|c|}{$42.9(6.0)$} & \multicolumn{2}{|c|}{$39.1(4.7)$} \\
\hline Mean (SD) driving experience (years) & \multicolumn{2}{|c|}{$10.4(4.4)$} & \multicolumn{2}{|c|}{$13.9(6.5)$} & \multicolumn{2}{|c|}{$9.5(4.9)$} \\
\hline
\end{tabular}

$S D=$ standard deviation 


\begin{tabular}{|c|c|c|c|c|c|c|c|}
\hline \multirow[t]{2}{*}{ Behaviour/experience } & \multicolumn{2}{|c|}{$\begin{array}{c}\text { Bus } \\
(n=302)\end{array}$} & \multicolumn{2}{|c|}{$\begin{array}{l}\text { Auto-rickshaw } \\
(n=301)\end{array}$} & \multicolumn{2}{|c|}{$\begin{array}{l}\text { Wagon } \\
(n=298)\end{array}$} & \multirow[t]{2}{*}{$P$-value } \\
\hline & No. & $\%$ & No. & $\%$ & No. & $\%$ & \\
\hline \multicolumn{8}{|l|}{ In previous 24 hours } \\
\hline \multicolumn{8}{|c|}{ Shouting, cursing or rude gestures } \\
\hline Happened to me & 33 & 10.9 & 55 & 18.3 & 26 & 8.7 & 0.010 \\
\hline I did to someone & 22 & 7.3 & 36 & 12.0 & 16 & 5.4 & 0.018 \\
\hline \multicolumn{8}{|c|}{ Threats to physically hurt the person or vehicle } \\
\hline Happened to me & 0 & 0.0 & 4 & 1.3 & 0 & 0.0 & $0.024^{\mathrm{a}}$ \\
\hline I did to someone & 0 & 0.0 & 3 & 1.0 & 0 & 0.0 & $0.073^{\mathrm{a}}$ \\
\hline \multicolumn{8}{|c|}{ In previous 3 months (excluding previous 24 hours) } \\
\hline \multicolumn{8}{|c|}{ Shouting, cursing or rude gestures } \\
\hline Happened to me & 237 & 78.5 & 287 & 95.3 & 264 & 88.6 & $<0.001$ \\
\hline I did to someone & 157 & 52.0 & 212 & 70.4 & 218 & 73.1 & $<0.001$ \\
\hline \multicolumn{8}{|c|}{ Threats to physically hurt the person or vehicle } \\
\hline Happened to me & 10 & 3.3 & 97 & 32.2 & 22 & 7.4 & $<0.001$ \\
\hline I did to someone & 8 & 2.6 & 58 & 19.3 & 20 & 6.7 & $<0.001$ \\
\hline
\end{tabular}

${ }^{a}$ Fisher exact test.

the previous 12 months, the differ- had accidents, $40.2 \%$ reportedly susence between drivers of the 3 types of tained injuries themselves and $17.9 \%$ commercial vehicles was not statisti- reported injuries to passengers of cally significant (9.9\% of bus, $13.3 \%$ their own vehicle or passengers/drivof auto-rickshaw and $14.2 \%$ of wagon ers of another vehicle. Out of the 20 drivers, $P=0.260$ ). Of the drivers who drivers who reported injuries in other people, 14 stated that 1 to 3 persons were injured. Interestingly, out of the 112 drivers who reported involvement in RTAs, $52.7 \%$ reported that the traffic police did not record the accident.

\begin{tabular}{|c|c|c|c|c|c|c|}
\hline \multirow[t]{2}{*}{ Experience of accidents } & \multicolumn{2}{|c|}{$\begin{array}{c}\text { Bus } \\
(n=30)\end{array}$} & \multicolumn{2}{|c|}{$\begin{array}{l}\text { Auto-rickshaw } \\
\qquad(n=40)\end{array}$} & \multicolumn{2}{|c|}{$\begin{array}{l}\text { Wagon } \\
(n=42)\end{array}$} \\
\hline & No. & $\%$ & No. & $\%$ & No. & $\%$ \\
\hline \multicolumn{7}{|c|}{ Involved in traffic accident in previous 12 months } \\
\hline Once & 30 & 100.0 & 35 & 87.5 & 41 & 97.6 \\
\hline Twice & 0 & 0.0 & 5 & 12.5 & 1 & 2.4 \\
\hline \multicolumn{7}{|c|}{$\begin{array}{l}\text { Got injuries that required visit to doctor/hospital or } \\
\text { self-treatment }\end{array}$} \\
\hline Yes & 14 & 46.7 & 14 & 35.0 & 17 & 40.5 \\
\hline No & 16 & 53.3 & 26 & 65.0 & 25 & 59.5 \\
\hline \multicolumn{7}{|c|}{$\begin{array}{l}\text { Someone else got injuries that required visit to } \\
\text { doctor/hospital or self-treatment }\end{array}$} \\
\hline Yes & 3 & 10.0 & 7 & 17.5 & 10 & 23.8 \\
\hline No & 27 & 90.0 & 33 & 82.5 & 32 & 76.2 \\
\hline \multicolumn{7}{|c|}{ No. of people injured in accident } \\
\hline $1-3$ & 1 & 3.3 & 7 & 17.5 & 6 & 14.3 \\
\hline $4-7$ & 1 & 3.3 & 0 & 0.0 & 4 & 9.5 \\
\hline$>7$ & 1 & 3.3 & 0 & 0.0 & 0 & 0.0 \\
\hline \multicolumn{7}{|c|}{ Accident was recorded by traffic police } \\
\hline Yes & 12 & 40.0 & 19 & 47.5 & 28 & 66.7 \\
\hline No & 18 & 60.0 & 21 & 52.5 & 14 & 33.3 \\
\hline
\end{tabular}




\section{Discussion}

Road safety is increasingly recognized as a major public health issue. The United Nations General Assembly has declared the 2011-20 as the Decade for Road Safety [6]. Annually road traffic injuries are sustained by 50 million individuals and kill about 1.3 million individuals globally, primarily in developing countries [7]. The results of this study are comparable to the few studies of road rage in the Eastern Mediterranean region and suggest that shouting, cursing or rude gestures are common form of road rage expression and experience in Pakistan [4,5]. Out of the 112 drivers who reported involvement in RTAs, $52.7 \%$ reported that traffic police did not record their accident. This finding calls into question the validity of the official roadside accident data and indicates that such records are an underestimate. In our study respondents were not asked why this was the case but future studies might need to look into the issue of under-reporting of RTAs.

Self-reporting of incidents was a major limitation of our study; however, trying to objectively determine road rage experiences and behaviours would be very challenging. Owing to the relatively small number of respondents reporting being involved in a RTA in the previous 12 months, the association between road rage and roadside accidents could not be discerned. Future studies could address this issue.

The results of this study indicate that road rage in commercial vehicle drivers is common in Lahore, underlining the need for nationally representative surveys to study road rage and its correlates, for better training of commercial vehicle drivers and health education campaigns to improve road safety in Pakistan.

\section{References}

1. Sansone RA, Sansone LA. Road rage: what's driving it? Psychiatry, 2010, 7:14-18.

2. Sansone RA, Lam C, Wiederman MW. Road rage: relationships with borderline personality and driving citations. International Journal of Psychiatry in Medicine, 2010, 40:21-29.

3. Roberts LD, Indermaur DW. The "homogamy" of road rage revisited. Violence and Victims, 2008, 23:758-772.

4. Shaikh IA et al. Road rage behavior: Experiences of university students. Journal of the College of Physicians and Surgeons--Pakistan, 2005, 15:830-831.

5. Shaikh IA, Shaikh MA, Siddiqui Z. Road rage behavior and experiences of bus and wagon drivers in Islamabad and
Rawalpindi. Journal of the Pakistan Medical Association, 2008, 58:220-221.

6. Decade of action for road safety 2011-2020 proclaimed by governments around the world [press release]. United Nations Road Safety Collaboration, 2010 (http://www.who.int/roadsafety/news/2010/unrsc_decade_of_action/en/index.html, accessed 1 March 2012).

7. The UN tackles road safety [press release]. World Health Organization, 3 March 2010 (http://www.who.int/mediacentre/ news/notes/2010/traffic_injuries_media_20100303/en/ index.html, accessed 1 March 2012). 